\title{
Unilateral Trade Preferences in the EU: An Empirical Assessment for the Case of Mozambican Exports
}

\author{
Xavier Cirera ${ }^{1}$ and Andrea Alfieri ${ }^{2}$ \\ ${ }^{1}$ Institute of Development Studies, University of Sussex, Brighton BN1 9RE, UK \\ ${ }^{2}$ Independent Consultant, Via Passo Bocco 1, Parma, Italy \\ Correspondence should be addressed to Xavier Cirera, x.cirera@ids.ac.uk \\ Received 4 August 2011; Revised 21 September 2011; Accepted 13 October 2011 \\ Academic Editor: Priya Ranjan
}

Copyright $\odot 2012$ X. Cirera and A. Alfieri. This is an open access article distributed under the Creative Commons Attribution License, which permits unrestricted use, distribution, and reproduction in any medium, provided the original work is properly cited.

\begin{abstract}
Unilateral trade preferences are one of the most important instruments offered by developed countries to foster developing country exports. This paper analyzes the impact of unilateral trade preferences on developing countries by focusing on the experience of Mozambique. In this paper, we analyze whether unilateral preferences offered by the EU are "valuable" for Mozambican exporters based on the impact on preferential margins, utilization rates, and export prices. We use a detailed dataset with cif unit values at HS8-digits level covering the period 2000-2007. Our findings indicate that (i) for a large number of product lines, export margins are zero; (ii) utilization rates are generally high; however, (iii) this does not translate into a positive price margins captured by Mozambican exporters compared to MFN competitors. These findings cast doubts on the "value" of preferences and their potential impact on developing country exports.
\end{abstract}

\section{Introduction}

Unilateral export preferences are an important trade policy tool for less developed countries (LDCs). Successive rounds of trade liberalization in developed countries under WTO agreements and the increasing number of preferential trade agreements (PTAs) have reduced the preferential margin that unilateral trade preferences provided. This so-called "erosion of preferences" has created concern among LDCs regarding the potential impact on their exports. However, the potential impact of "preference erosion" on LDCs depends on whether unilateral preferences are valuable.

This paper explores this issue using Mozambican exports to the EU as a case study. We focus on three main elements that may make unilateral preferences "valuable": (i) whether unilateral preferences have been used; (ii) whether preferences provide a significant tariff margin; (iii) the degree of appropriation of the price margin theoretically induced by the preference margin.

The paper is organized as follows. The following section gives a brief introduction to the economic rationale of export preferences and their expected impact. Section 3 analyzes preference utilization and price margins in Mozambican exports to the EU market. In Section 4, we employ econometric analysis in order to analyze in more detail the degree of passthrough from tariffs to price margins. The last section draws some conclusions.

\section{Unilateral Export Preferences}

2.1. Historical Background. Unilateral trade preferences are tariff concessions given by developed to developing countries that do not require reciprocity from beneficiary countries. There are several elements that justify the rationale of those preferences (see Hoekman and Özden [1] for a comprehensive survey). The main rationale is based on the notion of special and differential treatment (SDT) for developing countries (DCs) in multilateral trade agreements. The SDT principle draws upon the idea, widely influential in the 1950s and 1960s, that DCs needed to protect their markets in order to support infant industry and develop export manufacturing sectors. ${ }^{1}$

Existing unilateral export preferences were rationalized under United Nations Conference on Trade and Development (UNCTAD) in 1968 with the introduction of the Generalized System of Preferences (GSP), and GATT articles 
were amended in order to allow for discrimination. Since then, several other schemes have proliferated. The EU, for instance, granted unilateral preferences to former Africa, Caribbean, and Pacific colonies (ACP) in 1975 (the so-called Lomé Conventions) rationalized in 2000 under the Cotonou Agreement. The US targeted specific groups of commodities and countries with acts such as the Caribbean Basin Initiative (CBI). In addition, the last decade has also seen proliferation and expansion of the GSP, with the GSP-plus and the Everything but Arms (EBA) initiative granted by the EU to least developed countries (LDCs), or the African Growth Opportunity Act (AGOA) granted by the US to African countries.

Product coverage differs substantially, going from the nearly full coverage granted by EBA to roughly 6400 tariff lines in AGOA. Country coverage also varies, creating in some cases discrimination between DCs and LDCs. This has been the subject of some controversy. Commodityspecific provisions of the Cotonou Agreement, for instance, have been repeatedly challenged in the WTO (excluding banana and sugar). As a result, EU and ACP countries have been negotiating for a decade replacing Cotonou unilateral preferences by reciprocal free trade agreements (FTAs), the economic partnership agreements (EPAs). Other differences include rules on trade defense measures and, particularly, nontariff barriers such as rules of origin.

2.2. Economics of Unilateral Preferences. The analysis of unilateral export preferences is comparable to the analysis of free trade agreements. ${ }^{2}$ In a simple partial equilibrium framework, assuming perfect competition and product homogeneity across imports sources, we should expect that a small country receiving preferences and unable to affect the international price exports the product at the international price plus the tariff (Figure 1). Concretely, in the EU market, in the absence of any tariff for this product, equilibrium trade would be determined by the intersection between world supply at the international price $P^{\text {cif }}$ and net import demand $D$ at point $g$. However, by imposing a tariff $t$, the international price jumps to $P^{\text {cif }}(t)$ and the new equilibrium where world supply ROW $(t)$ meets net import demand $D$ reduces imports in the EU from $M$ to $M(t)$. In this case, Mozambican exporters represented by the supply schedule $\operatorname{Moz}(t)$ can supply $M^{\mathrm{moz}}(t)$, while world suppliers supply the remaining EU imports, $M(t)-M^{\mathrm{moz}}(t)$.

If the EU now grants preferential access to Mozambican exporters, firms can continue exporting at the international price plus the tariff $P^{\text {cif }}(t)$ but without having to bear the cost of the tariff. This increases their cost effectiveness vis-àvis world exporters and implies that, at $P^{\text {cif }}(t)$, Mozambican exporters can supply at point $c$, increasing exports from $M^{\mathrm{moz}}-M^{\mathrm{moz}}(t)$.

In this setting, the price margin, the difference between the price that the exporter would pay under MFN regime and under the preferential scheme $\left(P^{\text {cif }}(t)-P^{\text {cif }}\right)$, should be equal to the tariff margin, the difference between the MFN tariff, and the preferential tariff $(a-b)$.

Unilateral preferences, therefore, should have two main impacts. First, they allow the exporter to capture a higher price than otherwise it would have captured, the price wedge

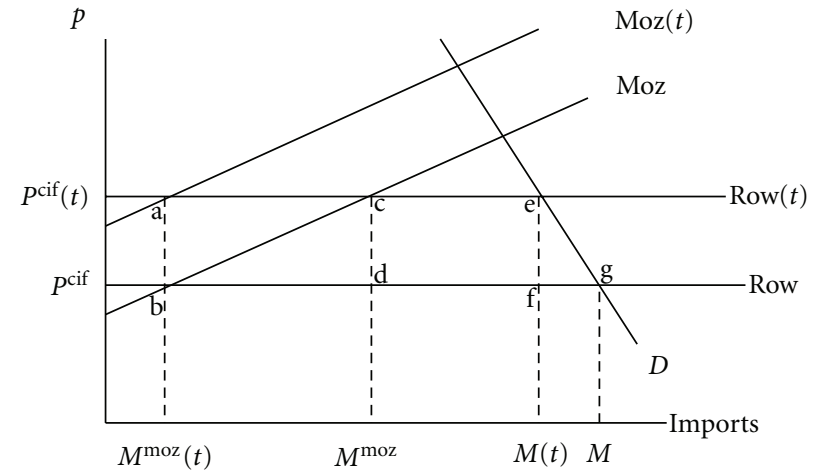

FIgURE 1: Unilateral preferences under perfect competition and homogenous products.

induced by the tariff $\left(P^{\text {cif }}(t)-P^{\text {cif }}\right)$. Second, the price margin allows the preferential exporter to export more quantity. Note that this is equivalent to the case of trade diversion, where unilateral preferences aim to divert trade and transfer revenue towards DCs.

It is difficult to assess the impact that unilateral exports preferences have had in practice so far. This impact seems to be product and country specific. However, it is clear in aggregate terms that unilateral export preferences have not achieved very large increases in exports or substantial production transformation towards manufactures in DCs and LDCs.

Several factors may explain this lack of success of unilateral preferences. First, some authors have suggested that costs caused by stringent rules of origin associated with these agreements may offset any advantage given by tariff concessions (see Carrere and de Melo [4] and Cadot et al. [5]). Second, some authors suggest that, with successive liberalization in OECD countries and the resultant preference erosion (see Hoekman et al. [6]), the preference margin has been substantially reduced to the point where it no longer provides a competitive advantage for some products. Finally, it is not necessarily the case that the price margin is transmitted to exporters. Due to market power on the importer side, a large share of the price wedge created by preferences may be appropriated by importers and not by exporters (Olarreaga and Özden [7] and Özden and Sharma [8]).

The following section assesses the impact of trade preference schemes granted by the EU to LDCs and DCs taking Mozambique as a case study.

\section{Mozambique Exports, Preference Margin, and Preference Utilization}

3.1. Overview of Mozambique Exports to the EU. The EU is the main destination for Mozambique's exports with more than $60 \%$ of total value exported. In 2007, the EU imported from Mozambique around $€ 1.9$ billion growing by a factor of twelve between 2000 and 2007.

A big expansion in export growth came in 2001 following the opening of a large aluminum smelter (Mozal). ${ }^{3}$ Despite this rapid growth, exports remain concentrated in very few 
TABLe 1: Main Mozambican export to the EU 2000/2007 by HS2 chapter.

\begin{tabular}{|c|c|c|c|}
\hline HS 2 chapter & Product & Value (millions EUR) & $\%$ share \\
\hline 76 & Aluminum and articles thereof & $11,437,495.00$ & $77.79 \%$ \\
\hline 3 & Fish and crustaceans & $1,508,769.60$ & $10.26 \%$ \\
\hline 24 & Tobacco and manufactured tobacco substitutes & $936,790.14$ & $6.37 \%$ \\
\hline 25 & $\begin{array}{l}\text { Salt; sulphur; earths and stone; plastering material, } \\
\text { lime, and cement }\end{array}$ & $267,836.09$ & $1.82 \%$ \\
\hline 17 & Sugars and sugar confectionery & $228,689.40$ & $1.56 \%$ \\
\hline 52 & Cotton & $115,070.22$ & $0.78 \%$ \\
\hline 8 & Edible fruit and nuts; peel of citrus fruits or melons & $82,720.88$ & $0.56 \%$ \\
\hline 44 & Wood and articles of wood; wood charcoal & $52,284.92$ & $0.36 \%$ \\
\hline 27 & $\begin{array}{l}\text { Mineral fuels, mineral oils, and products of their } \\
\text { distillation; bituminous substances; mineral waxes }\end{array}$ & $20,881.43$ & $0.14 \%$ \\
\hline 9 & Coffee and tea & $16,185.38$ & $0.11 \%$ \\
\hline 41 & Raw hides and skin leathers & $11,103.54$ & $0.08 \%$ \\
\hline 12 & $\begin{array}{l}\text { Oil seeds and oleaginous fruits; miscellaneous grains, } \\
\text { seeds, and fruit; industrial or medical plants; straw and } \\
\text { fodder }\end{array}$ & $10,030.34$ & $0.07 \%$ \\
\hline 56 & $\begin{array}{l}\text { Wadding, felt, and nonwovens; special yarns; twine, } \\
\text { cordage, rope and cable, and articles thereof }\end{array}$ & $6,583.09$ & $0.04 \%$ \\
\hline 61 & $\begin{array}{l}\text { Articles of apparel and clothing accessories, knitted, or } \\
\text { crocheted }\end{array}$ & $3,599.13$ & $0.02 \%$ \\
\hline 64 & Footwear & $1,275.65$ & $0.01 \%$ \\
\hline
\end{tabular}

Source: authors' calculations based on EUROSTAT.

products. Table 1 reports the value of main exports (HS2) between 2000 and $2007 .{ }^{4}$ In this period, a mere five chapters amounted to around $98 \%$ of the total value exported to the EU. Unwrought aluminum alone represented $77 \%$ of total exports, followed by fish and crustaceans and tobacco products with, respectively, $10.3 \%$ and $6.37 \%$. If we exclude occasional exports ${ }^{5}$ from the analysis, we can identify 55 products at HS 8-digits as main exports over the period 2000-2007.

At first glance, what emerges from the data is the low level of processing of Mozambican exports, clustered around primary agriculture products, low-processed fishery products, and mineral resources. Cotton is only ginned in Mozambique, while tobacco and wood products are exported mainly not manufactured.

Mozambique enjoyed preferential market access for exports to the EU through different schemes: the Cotonou Agreement, replaced in 2008 by the EPAs and the EBA initiative. Coverage, tariff margins and compliance procedures ${ }^{6}$ vary between the schemes. For instance, the former offers reduced tariffs, while the latter offers duty-free access for almost all products covered.

3.2. Preference Margins for Mozambican Exports. The main data source for the analysis is the EUROSTAT COMEXT database. It includes information on volume, quantities, country of origin, and whether exports were eligible and used preferences. It is important to point out that by preference use we understand whether preferences were requested, since the database does not provide information on whether preferential regime was rejected at EU arrival. ${ }^{7}$ As the product price, we use the unit value obtained by dividing the value of exports with the correspondent number of tons or items. All unit values are expressed as Euro $(€)$ cif values per ton. Working with unit values is a challenging exercise, since errors can be made inputting either values, quantities, or both, and, therefore, distorting unit values. As a result, we first filter the data using Hadi's [10] methodology, in order to eliminate outliers. ${ }^{8}$

Any Mozambican export is eligible for duty-free access under the EBA initiative. ${ }^{9}$ This has two implications: (i) the preference margin potentially available for Mozambique is basically the full MFN tariff since the preferential tariff is zero, and (ii) any access through the MFN regime would automatically signal nonuse of preferences (see next section for an assessment of utilization rates in Mozambique).

In terms of MFN tariffs, more than $42 \%$ of the tariff lines analyzed had MFN duty-free access. ${ }^{10}$ For these products (mainly cotton, tea, paprika, copra, and wood products), any preferential access is, therefore, irrelevant, although in terms of value these products represent only a mere $5.4 \%$ of total exports. Aluminum, which is almost $80 \%$ of total export value, faces a MFN tariff greater than zero (6\%).

We define the preference margin as the difference between the MFN tariff and the tariff actually applied on good $i$ exported by Mozambique at time $t$ :

$$
\text { Margin_pref } f_{i, t}=\mathrm{MFN}_{i, t}-\text { Tariff }_{i, t} .
$$

If the MFN tariff is equal to the tariff applied or it is zero, then it means that there is no positive preference margin and Margin_pref will take the value zero. On the other hand, if the MFN tariff is greater than the applied tariff, then there is potential use of preference, and Margin_pref will be 
TABLe 2: Average preference margins (Mozambique).

\begin{tabular}{|c|c|c|c|c|}
\hline \multicolumn{3}{|c|}{ Average preference margin (all tariff lines) } & \multicolumn{2}{|c|}{ Average preference margin (tariff lines with MFN $>0$ only) } \\
\hline Year & Average & Max & Year & Average \\
\hline 2000 & $5.13 \%$ & $15.00 \%$ & 2000 & $8.51 \%$ \\
\hline 2001 & $6.39 \%$ & $63.05 \%$ & 2001 & $9.94 \%$ \\
\hline 2002 & $7.34 \%$ & $82.80 \%$ & 2002 & $12.45 \%$ \\
\hline 2003 & $6.72 \%$ & $82.31 \%$ & 2003 & $10.55 \%$ \\
\hline 2004 & $5.67 \%$ & $80.91 \%$ & 2004 & $9.85 \%$ \\
\hline 2005 & $5.92 \%$ & $86.37 \%$ & 2005 & $10.79 \%$ \\
\hline 2006 & $6.49 \%$ & $69.68 \%$ & 2006 & $12.94 \%$ \\
\hline 2007 & $7.12 \%$ & $69.68 \%$ & 2007 & $13.33 \%$ \\
\hline
\end{tabular}

Source: authors' calculations based on TARIC and EUROSTAT.

Note by the authors: the substantial change in the max preference margin is due to the specific duties applied to sugar.

positive. Theoretically, due to EBA, any export should enter the EU duty free (MFN equals preference margin). However, since some Mozambican exports entered using Cotonou's preferences, in some cases, we expect tariff margins lower than MFN. Alfieri and Cirera [11] show that in practice a significant share of exports (49\%) does not benefit from any margin of preference. For a large share of observations $(42.3 \%)$, this is explained by the fact that MFN is already zero, while for the remaining cases it is due to nonuse of preferences $(6.7 \%)$.

On average, the preference margin enjoyed by Mozambican exports is between 5\% and 7\% (See Table 2). MFN and preferential tariffs have been slightly modified during the period, ${ }^{11}$ and part of the variation is also explained by few tariff lines facing seasonal or specific duties (agricultural products). Excluding the tariff lines already liberalized at MFN level, the average preference margin is between $8.5 \%$ and $13.3 \%$.

3.3. Price Margins for Mozambican Exports. As discussed in Section 2.2, we should expect (i) Mozambican exporters to get a higher price compared to MFN exporters of the same good in the same period; (ii) the difference in prices being equal to the preference margin.

The main challenge when analyzing price margins is the lack of counterfactual. This implies that we do not observe the MFN price for most periods since most exports use preferential schemes. Interestingly, in our sample, we find cases of Mozambican firms exporting the same good through the MFN regime and also via preferential schemes, in the same year or the same month. These are cases where both utilization and nonutilization of preferences occur in the same period. As a result, we use nonutilization prices as one of the main reference prices to further reduce the potential quality bias and compare the results using alternative reference MFN prices. ${ }^{12}$ We define $P_{\text {cif }} \mathrm{MFN}_{1}$ to $P_{\text {cif }} \mathrm{MFN}_{4}$ as follows: ${ }^{13}$

(i) $P_{\text {cif }} \mathrm{MFN}_{1}$ - the unit value paid to Mozambican exporters when they do not use preferences. This reference price eliminates potential quality biases, since it is the same product exported also under preferential use; (ii) $P_{\text {cif }} \mathrm{MFN}_{2}$ - the minimum unit value paid to $\mathrm{MFN}$ exporters in the same month;

(iii) $P_{\text {cif }} \mathrm{MFN}_{3}$ - the average cif unit value paid to MFN exporters in the same month;

(iv) $P_{\text {cif }} \mathrm{MFN}_{4}$ - the cif unit value paid to the largest MFN exporter in the same month. We then construct price ratios as unit values recorded under preference over reference MFN unit values:

$$
\text { Margin_price }_{k}=\log \left(\frac{P_{\text {cif }} \text { Mozambique }_{i, t}}{P_{\text {cif }} \mathrm{MFN}_{k}}\right) \text {, }
$$

where $P_{\text {cif }}$ Mozambique $_{i, t}$ is the cif unit value paid to the export of good $i$ in month $t$ and the denominator is alternatively one of the four reference prices described above.

Figure 4 shows the probability distribution functions of Margin_price $_{1}$ to Margin_price 4 . For a large number of observations the price paid to Mozambican exporters is actually lower than the MFN reference prices used. Using $P_{\text {cif }} \mathrm{MFN}_{1}$, we have a positive price margin only for $53 \%$ of the observations, for $P_{\text {cif }} \mathrm{MFN}_{3}, 34 \%$ of observations have a positive margin, and, for $P_{\text {cif }} \mathrm{MFN}_{4}$, around $44 \%$ of observations are positive. However, for $P_{\text {cif }} \mathrm{MFN}_{2}$, this figure raises up to $85 \%$. As expected, price margin ratios 3 and 4 tend to have lower preferential unit values, since we are comparing them with average and larger exporter unit value, likely to be a richer country that produces higher quality goods. While ratio 2 tends to be positive since we use the minimum unit value as reference. This implies a potential quality bias when using these ratios. The most interesting result is, however, when comparing underprice margin ratio 1 , unit values under utilization and nonutilization of preferences in the same period and product, for controlling for quality differentials. In this case, the probability of a larger preferential price is only of $53 \%$.

At the product level, we find that only five products always report price ratios above one, consistent with a positive tariff margin. ${ }^{14}$ At first glance, it seems that Mozambican exporters are not always capturing a higher price than MFN competitors even in the presence of positive preference margins. 
It is important to point out that when using price margin 1 , the results may be biased due the reasons behind preference nonutilization. Preferential exports need additional documentation (i.e., certificate of origin to be provided by public authorities). If there is a delay in obtaining such documents, the exporter may choose to export via MFN in order to honor the export contract, especially when delays may trigger penalties or in case of perishable goods. ${ }^{15}$ Thus, in the presence of rigid contract prices, exporters may be unable to pass MFN duties now being paid into the cif price.

3.4. Preference Utilization. A final element that needs to be assessed when analyzing the "value" of preferences is the degree of preference utilization by Mozambican exporters. ${ }^{16} \mathrm{~A}$ widespread critique made to preferential schemes is that often the products covered are the ones scarcely exported by the beneficiaries. ${ }^{17}$ In the case of Mozambique, this critique could be applied to the Cotonou Agreement, where only a few agricultural products offer preferential access, but not for the EBA initiative, since the few excluded products from preferential access (i.e., rice, banana) are not being exported and sugar is exported at very favorable price (and with increasing quotas).

For those lines with MFN greater than zero, Mozambique shows a high utilization rate, on average across products and years equal to $93 \%$ of the value of eligible exports. Manchin [14] finds an average utilization rate of Cotonou for nonLDCs in the range of $50 \%$ in 2000 and a much lower for GSP (6\%). In the same year, Mold [15] finds an average utilization rate for GSP of $41 \%$ for African LDCs. However, both examine only one scheme and do not take into account competing schemes as we do. In a broader evaluation of EU preferential schemes, OECD [16] finds that utilization rates are much higher than commonly thought when competing schemes are taken into account. This is confirmed by our findings for the case of Mozambique.

There are two main potential explanations for lack of preference utilization. The first explanation is related to the costs of compliance attached to preferential schemes and induced by rules of origin (Cadot et al., [5]). Carrere and de Melo [4] estimate (nonparametrically) such costs for EU preferential schemes and FTAs (PANEURO) between $4.7 \%$ and $8.2 \%$ of the cif export price. Manchin [14] obtains a similar estimate $(4.5 \%)$ for a preference threshold below which traders do not have the incentive to request preferences. Under this argument, preferences are only used if the expected price gain exceeds the costs of compliance. However, as shown in Section 3.3, such a link seems weak in the case of Mozambique.

The second explanation for nonutilization is related to the delays by public authorities in delivering documentation for preferential export. Considering this explanation, we should observe unexpected jumps in preference utilization uncorrelated with price or tariff margins (random events due to random delays).

In Figure 2, we plot the utilization rates against the (yearly average) MFN tariff. There is no indication of a substantial drop in utilization rates when the MFN tariff is below a certain threshold. Even at the product level, the products

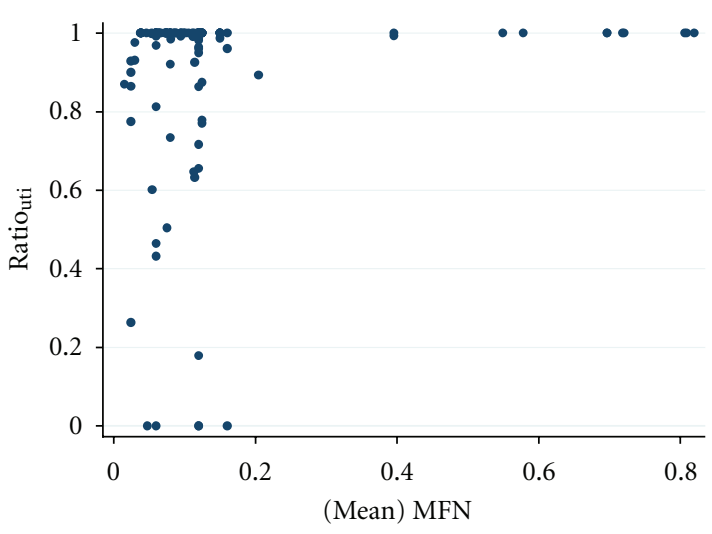

Figure 2: Utilization rates and MFN tariff (Mozambique). Source: authors' calculations.

showing the highest nonutilization rates do not necessarily display the lowest MFN tariffs (See Table 3).

The existing narrow export base in Mozambique implies that each product is probably exported by one or two firms. At the same time, preference margins have been quite stable over time. If the cost of compliance would impact significantly the choice of trade regime, we would expect lower utilization for products facing low MFN tariffs. In contrast, in our data, we observe high utilization rates across products and few isolated drops in utilization rates. Therefore, unforeseen administrative problems may be a much more likely explanation for the discontinuous utilization rates in Mozambique, and any estimates of average costs of compliance would ignore the fact that we observe utilization of preferences at very low preferential margins.

So far, we have performed an analysis based on simple correlations. However, it is possible that this analysis is not able to isolate the quality bias when comparing products. In addition, we cannot exclude that other factors other than tariff differentials may impact on price margins. For these reasons, we now proceed to test econometrically the relationship between prices and preference margins.

\section{Econometric Estimations}

4.1. Analytical Framework. The starting point is to assume that the price of the same good in the same period in the EU market is the same for imports under the MFN and under the preferential scheme. Since most of the products in the sample are primary commodities, it is therefore plausible to assume that these are homogenous products. However, in order to allow for some quality differences that may arise when using alternative reference MFN prices, we allow for a quality adjustment $\delta_{i}$ (3). We assume that the quality differential is product specific and constant over time and that it is zero when using the same country reference MFN price. This is represented in (3), where the price of good $i$ from country $j$ in year $t$ not eligible for preferences, and therefore entering via MFN, $P_{i j t}^{\mathrm{MFN}}$, is equal to the price of good $i$ from country $k$ in year $t$ eligible for preferences, $P_{i k t}^{\text {pref }}$, plus the quality adjustment term $\left(1+\delta_{i}\right)$. 
TABle 3: Products showing highest nonutilization rates.

\begin{tabular}{lccc}
\hline HS8 & Product & Nonutilization rates & Average MFN tariff \\
17031000 & Cane molasses & $47.37 \%$ & $3.49 \%$ \\
\hline 08051030 & Fresh navels & $28.63 \%$ & $17.11 \%$ \\
61091000 & T-shirts, knitted or crocheted & $26.34 \%$ & $12.00 \%$ \\
56072100 & Binder twine of sisal & $24.70 \%$ & $12.00 \%$ \\
08054000 & Fresh or dried grapefruit & $23.31 \%$ & $2.25 \%$ \\
\hline
\end{tabular}

Source: authors' calculations.

The price paid for good $i$ by the exporter from country $j$ under the MFN regime, $P_{i j t}^{\mathrm{MFN}}$, is the cif unit value $P_{i j t}^{\mathrm{cif}}$ times the MFN tariff $\left(1+\tau_{i j t}\right)$ and a variable that reflects its market power $\left(1+m_{i j t}\right)(4)$. On the other hand, the preferential price, $P_{i k t}^{\text {pref }}$, is defined by the cif unit value, $P_{i k t}^{\text {cif }}$, times the preferential tariff $\left(1+\tau^{\text {pref }}\right)$, a margin that represents the market power of the exporter relative to the importer $(1+$ $\left.m_{i k t}\right)$, which is proxied by its relative market share, and the compliance $\operatorname{cost}^{18}$ associated to the scheme, also assumed product specific and constant over time $\left(1+c_{i}\right)(5)$.

Substituting (4) and (5) into (3), we obtain (6), and taking logs and adding an error term, we obtain (7). Equation (7) implies that the ratio of prices (preferential over MFN) should be explained by the tariff margin ratio, the relative market power between exporters relative to importers, the inverse of the cost of compliance, and the product specific quality adjustment:

$$
\begin{gathered}
P_{i j t}^{\mathrm{MFN}}=\left(1+\delta_{i}\right) P_{i k t}^{\mathrm{pref}}, \\
P_{i j t}^{\mathrm{MFN}}=P_{i j t}^{\mathrm{cif}}\left(1+\tau_{i j t}\right)\left(1+m_{i j t}\right), \\
P_{i k t}^{\mathrm{pref}}=P_{i k t}^{\mathrm{cif}}\left(1+\tau_{i k t}^{\mathrm{pref}}\right)\left(1+m_{i k t}\right)\left(1+c_{i}\right), \\
\frac{P_{i k t}^{\mathrm{cif}}}{P_{i j t}^{\mathrm{cif}}}=\frac{\left(1+\tau_{i j t}\right)\left(1+m_{i j t}\right)}{\left(1+\tau_{i k t}^{\text {pref }}\right)\left(1+m_{i k t}\right)\left(1+c_{i}\right)\left(1+\delta_{i}\right)}, \\
\ln \left(\frac{P_{i k t}^{\mathrm{cif}}}{P_{i j t}^{\mathrm{cif}}}\right)=\alpha+\beta \ln \left(\frac{1+\tau_{i j t}}{1+\tau_{i k t}^{\text {pref }}}\right)+\delta \ln \left(\frac{1+m_{i j t}}{1+m_{i k t}}\right) \\
\ln \left(\frac{P_{i k t}^{\mathrm{cif}}}{P_{i j t}^{\mathrm{cif}}}\right)=\alpha \ln \left(\frac{1}{\left(1+c_{i}\right)\left(1+\delta_{i}\right)}\right)+\varepsilon_{i k t}, \\
\alpha+\beta \ln \left(\frac{1+\tau_{i j t}}{1+\tau_{i k t}^{p r e f}}\right) \\
+\delta \ln \left(\frac{1+m_{i j t}}{1+m_{i k t}}\right)+\phi_{i}+\varepsilon_{i k t .}
\end{gathered}
$$

We expect to find a positive sign for $\beta$, since an increase in the tariff margin would imply a higher price for the exporter using preferences. We expect to find a negative sign for $\delta$, since a higher market power of MFN exporters compared to those exporting preferentially would imply less bargaining power. Because compliance costs and quality differentials are unobservable, the assumption that these elements are constant over time allows us to treat them as product fixed effects $\phi$. A priori we should not expect any significant changes of these two elements over the sample period.

Equation (5) is, therefore, estimated using a monthly panel of 55 products exported from Mozambique from 2000 to 2007, which represents more than $99 \%$ value of Mozambican exports to the EU. As a dependent variable, we alternatively use the price ratios defined in Section 3.3. Our preferred specification is price ratio 1 , which compares utilization and nonutilization unit values when they occur in the same period and, therefore, minimizes any quality differential bias $\left(\delta_{i}=0\right)$, since we are comparing exporters from the same product and year. This, however, reduces the sample to 98 observations. As a result, we also compare the results with the estimates using the other three alternative reference prices, which provide some sensitivity analysis.

As tariff ratio, we use MFN and preferential tariffs faced by country $j$ exporting product $i$ in month $t$. As proxy for relative margins, we take the ratio between the average market share of countries exporting product $i$ through MFN during the year $t$ and the market share of a country $j$ exporting product $i$ in year $t .{ }^{19}$ Finally, regarding the unobserved quality differences and costs of compliance, we treat them as product fixed effects. The fact that the coefficients are absorbed by product dummies implies that we cannot identify both variables. However, our main interest is the passthrough coefficient from preference margins to prices. In addition, as discussed above, although some authors have used average estimates of compliance costs based in parametric or nonparametric estimates (see Carrere and de Melo, [4]), we find large utilization occurring at very low preferential margins (i.e., 3\%) or high nonutilization rates occurring at high preferential margins (i.e., 11.20\%). For this reason, we believe that compliance costs are better modeled as product specific dummies.

Since it is possible that product-fixed effects may not fully control for such quality differences, we introduce a further control and estimate (8) in first differences (yearly) using OLS as in (9) below. The assumption here is that if the quality differences are time invariant, they will be wiped out in the differences model:

$$
\begin{aligned}
\Delta \ln \left(\frac{P_{i k t}^{\mathrm{cif}}}{P_{i j t}^{\mathrm{cif}}}\right)_{t ; t-1}= & \beta \Delta \ln \left(\frac{1+\tau_{i j t}}{1+\tau_{i k t}^{\mathrm{pref}}+\tilde{c}}\right)_{t ; t-1} \\
& +\delta \Delta \ln \left(\frac{1+m_{i j t}}{1+m_{i k t}}\right)_{t ; t-1}+\varepsilon_{i k t} .
\end{aligned}
$$


Table 4: Price margin estimates.

\begin{tabular}{|c|c|c|c|c|c|c|c|c|}
\hline & $\begin{array}{c}(1) \\
\text { Ratio } 1 \\
\text { FE }\end{array}$ & $\begin{array}{c}(2) \\
\text { Ratio } 1 \\
\text { RE }\end{array}$ & $\begin{array}{c}(3) \\
\text { Ratio } 2 \\
\text { FE }\end{array}$ & $\begin{array}{c}(4) \\
\text { Ratio } 2 \\
\text { RE }\end{array}$ & $\begin{array}{c}(5) \\
\text { Ratio } 3 \\
\text { FE }\end{array}$ & $\begin{array}{c}(6) \\
\text { Ratio } 3 \\
\text { RE }\end{array}$ & $\begin{array}{c}(7) \\
\text { Ratio } 4 \\
\text { FE }\end{array}$ & $\begin{array}{c}(8) \\
\text { Ratio } 4 \\
\text { RE }\end{array}$ \\
\hline Tariff ratio & $\begin{array}{l}-10.6234 \\
(14.5113)\end{array}$ & $\begin{array}{l}-1.0725 \\
(0.8414)\end{array}$ & $\begin{array}{c}-3.5494^{* * *} \\
(0.4325)\end{array}$ & $\begin{array}{c}-3.4203 * * * \\
(0.4055)\end{array}$ & $\begin{array}{c}-1.7310^{* * *} \\
(0.2638)\end{array}$ & $\begin{array}{c}-1.3966^{* * *} \\
(0.2368)\end{array}$ & $\begin{array}{c}-1.4366^{* * *} \\
(0.3195)\end{array}$ & $\begin{array}{c}-1.2634^{* * *} \\
(0.2951)\end{array}$ \\
\hline Market share & $\begin{array}{l}-0.1305 \\
(0.1641)\end{array}$ & $\begin{array}{l}-0.0532 \\
(0.1365)\end{array}$ & $\begin{array}{c}0.2562 \\
(0.1331)\end{array}$ & $\begin{array}{l}0.3207^{*} \\
(0.1303)\end{array}$ & $\begin{array}{l}-0.0538 \\
(0.0812)\end{array}$ & $\begin{array}{l}-0.0426 \\
(0.0782)\end{array}$ & $\begin{array}{l}-0.1007 \\
(0.0983)\end{array}$ & $\begin{array}{l}-0.0703 \\
(0.0957)\end{array}$ \\
\hline Constant & $\begin{array}{c}0.8903 \\
(1.2061)\end{array}$ & $\begin{array}{c}0.1432 \\
(0.1041)\end{array}$ & $\begin{array}{c}0.8399 * * * \\
(0.0339)\end{array}$ & $\begin{array}{c}0.7040^{* * *} \\
(0.1139)\end{array}$ & $\begin{array}{c}-0.1031^{* * *} \\
(0.0207)\end{array}$ & $\begin{array}{c}-0.1769 * * \\
(0.0542)\end{array}$ & $\begin{array}{l}-0.0296 \\
(0.0251)\end{array}$ & $\begin{array}{l}-0.0590 \\
(0.0764)\end{array}$ \\
\hline Obs. & 98 & 98 & 1917 & 1917 & 1916 & 1916 & 1915 & 1915 \\
\hline$R$-squared & 0.0114 & & 0.0371 & & 0.0228 & & 0.0112 & \\
\hline$R 2$ within & 0.0114 & 0.00744 & 0.0371 & 0.0369 & 0.0228 & 0.0228 & 0.0112 & 0.0112 \\
\hline$R 2$ between & 0.113 & 0.104 & 0.117 & 0.125 & $5.90 e-05$ & $6.22 e-05$ & 0.000362 & 0.000639 \\
\hline$R 2$ overall & 0.0236 & 0.0225 & 0.0996 & 0.106 & 0.00278 & 0.00277 & 0.000911 & 0.000920 \\
\hline
\end{tabular}

Robust standard errors in parentheses.

$* * * P<0.001, * * P<0.01, * P<0.05$.

The coefficients in (9) can be interpreted as elasticities with respect to changes in price margins, and the expected signs of the coefficients are the same as described in (8).

4.2. Data and Results. After cleaning for outliers, we obtain a dataset with 2,088 observations for 55 products defined at HS-8 digits. Trade flows are differentiated on the basis of access regime: MFN zero (42.34\%), MFN positive or nonutilization of preferences $(6.70 \%)$, preferential tariff zero $(50.4 \%)$ or greater than zero $(0.57 \%)$.

We estimate (7) using fixed effects (FEM) and random effects (REM) estimators in order to capture unobserved quality factors and costs of compliance. Table 4 shows the estimates for the four price ratio specifications. Columns (1) to (2) show the results for the preferred specification where the MFN price is proxied by the nonutilization of preferences unit values. Since the frequency of nonutilization is low, the shortcoming of this specification is the fact that the sample is reduced to only 98 episodes where both utilization and nonutilization of preferences occur for the same product and month. The results suggest that, contrary to the expected, preference margins are negatively transmitted to price margins, although the coefficients are not statistically significant. Despite that this specification is more likely to control for any quality differentials, the small sample is a constraint to obtain robust results.

Columns (3) to (8) show the estimates for the rest of price ratios specifications. In this case, we have around 1900 observations. We implement the Hausman test for fixed versus random effects, and the test results indicate that, only for price ratio 2 , the ratio between the preferential unit value, and the minimum MFN unit value, the RE specification should be preferred. The main results are consistent across specification, a negative and statistically significant coefficient for the preference margin and negative but not statistically significant for the market share ratio coefficients. The results also show consistent low $R^{2}$, suggesting the omission of important elements explaining this price ratio.

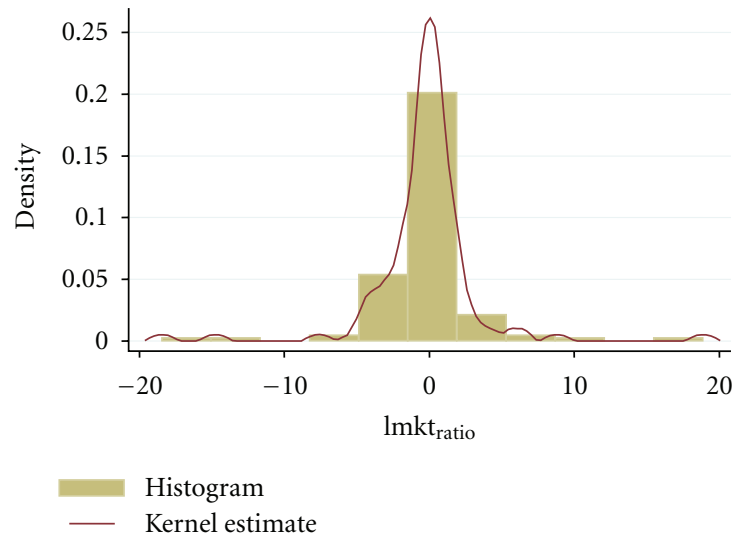

Figure 3: Distribution functions for estimated $\beta$ for tariff ratios.

Overall and contrary to what should be expected, preference margins are associated with lower preferential prices.

In order to check the heterogeneity of results, we reestimate the model for each product. For some products identification of the coefficient for the preference margin proves difficult to estimate due to the lack of tariff margin variation. Figure 3 shows the distribution of all the estimated coefficients for tariff margins when estimating (7) individually for each product when the sample is larger than 15 observations. The distribution is skewed to the left of zero, indicating a larger number of negative estimated coefficients. In terms of specific products, only five products show consistent positive passthrough from tariff margins to price margins: 3061350 frozen prawns, 08051030 fresh navels, 17011110 raw cane sugar, and 56072100 and 56072910 twine and textile fibers. All these coefficients are, however, not statistically significant.

To further eliminate the potential quality bias when using other countries MFN prices as reference (price ratios 2 to 4 ), we reestimate the same specifications but changing the way how the unit values are calculated. Unit values tend to be correlated with GDP per capita levels. As a result, we adjust 
TABle 5: Price margin estimates-GDP per capita adjusted.

\begin{tabular}{|c|c|c|c|c|c|c|}
\hline & $\begin{array}{c}(1) \\
\text { Ratio } 2 \\
\text { FE }\end{array}$ & $\begin{array}{c}(2) \\
\text { Ratio } 2 \\
\text { RE }\end{array}$ & $\begin{array}{c}(3) \\
\text { Ratio } 3 \\
\text { FE }\end{array}$ & $\begin{array}{c}(4) \\
\text { Ratio } 3 \\
\text { RE }\end{array}$ & $\begin{array}{c}(5) \\
\text { Ratio } 4 \\
\text { FE }\end{array}$ & $\begin{array}{c}(6) \\
\text { Ratio } 4 \\
\text { RE }\end{array}$ \\
\hline Tariff ratio & $\begin{array}{l}-0.0757 \\
(0.0482)\end{array}$ & $\begin{array}{l}-0.0539 \\
(0.0353)\end{array}$ & $\begin{array}{c}-0.1341^{* *} \\
(0.0431)\end{array}$ & $\begin{array}{c}-0.1205^{* * *} \\
(0.0353)\end{array}$ & $\begin{array}{l}0.0287^{*} \\
(0.0137)\end{array}$ & $\begin{array}{c}0.0348^{* *} \\
(0.0112)\end{array}$ \\
\hline Market share & $\begin{array}{c}0.0274 \\
(0.0209)\end{array}$ & $\begin{array}{l}0.0359^{*} \\
(0.0172)\end{array}$ & $\begin{array}{c}0.0214 \\
(0.0187)\end{array}$ & $\begin{array}{l}0.0359^{*} \\
(0.0166)\end{array}$ & $\begin{array}{c}0.0009 \\
(0.0059)\end{array}$ & $\begin{array}{l}-0.0029 \\
(0.0053)\end{array}$ \\
\hline Constant & $\begin{array}{c}-0.0166^{* * *} \\
(0.0042)\end{array}$ & $\begin{array}{c}-0.0195^{* *} \\
(0.0063)\end{array}$ & $\begin{array}{c}-0.0788^{* * *} \\
(0.0038)\end{array}$ & $\begin{array}{c}-0.0791^{* * *} \\
(0.0070)\end{array}$ & $\begin{array}{c}-0.0407^{* * *} \\
(0.0012)\end{array}$ & $\begin{array}{c}-0.0413^{* * *} \\
(0.0022)\end{array}$ \\
\hline Observations & 352 & 352 & 351 & 351 & 352 & 352 \\
\hline$R$-squared & 0.0133 & & 0.0349 & & 0.0148 & \\
\hline$R 2$ within & 0.0133 & 0.0120 & 0.0349 & 0.0326 & 0.0148 & 0.0138 \\
\hline$R 2$ between & 0.0549 & 0.0721 & 0.0920 & 0.118 & 0.103 & 0.125 \\
\hline$R 2$ overall & 0.0335 & 0.0419 & 0.0872 & 0.112 & 0.0729 & 0.0797 \\
\hline
\end{tabular}

Robust standard errors in parentheses.

${ }^{* * *} P<0.001,{ }^{* *} P<0.01,{ }^{*} P<0.05$.

TABle 6: Price margin estimates-model in differences.

\begin{tabular}{|c|c|c|c|c|c|c|c|c|c|}
\hline Variables & $\begin{array}{c}(1) \\
\text { Ratio } 2 \\
\text { OLS }\end{array}$ & $\begin{array}{c}(2) \\
\text { Ratio } 2 \\
\text { FE }\end{array}$ & $\begin{array}{c}(3) \\
\text { Ratio } 2 \\
\text { RE }\end{array}$ & $\begin{array}{c}(4) \\
\text { Ratio } 3 \\
\text { OLS }\end{array}$ & $\begin{array}{c}(5) \\
\text { Ratio } 3 \\
\text { FE }\end{array}$ & $\begin{array}{c}(6) \\
\text { Ratio } 3 \\
\text { RE }\end{array}$ & $\begin{array}{c}(7) \\
\text { Ratio } 4 \\
\text { OLS }\end{array}$ & $\begin{array}{c}(8) \\
\text { Ratio } 4 \\
\text { FE }\end{array}$ & $\begin{array}{c}(9) \\
\text { Ratio } 4 \\
\text { RE }\end{array}$ \\
\hline L. traiff ratio & $\begin{array}{c}-1.8364^{*} \\
(0.8842)\end{array}$ & $\begin{array}{c}0.0982 \\
(2.0520)\end{array}$ & $\begin{array}{l}-1.2985 \\
(1.0787)\end{array}$ & $\begin{array}{c}0.5135 \\
(0.5255)\end{array}$ & $\begin{array}{c}0.1403 \\
(1.3303)\end{array}$ & $\begin{array}{c}0.5270 \\
(0.5460)\end{array}$ & $\begin{array}{c}0.1211 \\
(0.6598)\end{array}$ & $\begin{array}{c}0.2224 \\
(1.4369)\end{array}$ & $\begin{array}{c}0.2347 \\
(0.6027)\end{array}$ \\
\hline $\begin{array}{l}\text { L. market } \\
\text { share }\end{array}$ & $\begin{array}{c}2.2838^{* * *} \\
(0.5181)\end{array}$ & $\begin{array}{l}1.5857^{*} \\
(0.6754)\end{array}$ & $\begin{array}{c}1.9810^{* * *} \\
(0.5139)\end{array}$ & $\begin{array}{c}0.3694 \\
(0.2347)\end{array}$ & $\begin{array}{l}0.9140^{*} \\
(0.4379)\end{array}$ & $\begin{array}{l}0.6267^{*} \\
(0.2816)\end{array}$ & $\begin{array}{l}0.6510^{*} \\
(0.3154)\end{array}$ & $\begin{array}{c}0.6180 \\
(0.4730)\end{array}$ & $\begin{array}{l}0.7496^{*} \\
(0.3094)\end{array}$ \\
\hline Constant & $\begin{array}{c}0.6345^{* * *} \\
(0.1780)\end{array}$ & $\begin{array}{c}0.6415^{* * *} \\
(0.1590)\end{array}$ & $\begin{array}{c}0.5535^{* *} \\
(0.1716) \\
\end{array}$ & $\begin{array}{c}-0.3863^{* * *} \\
(0.0929)\end{array}$ & $\begin{array}{c}-0.4528^{* * *} \\
(0.1031)\end{array}$ & $\begin{array}{c}-0.4514^{* * *} \\
(0.0859)\end{array}$ & $\begin{array}{c}-0.3130^{* *} \\
(0.0979)\end{array}$ & $\begin{array}{c}-0.3132^{* *} \\
(0.1113) \\
\end{array}$ & $\begin{array}{c}-0.3525^{* * *} \\
(0.0948)\end{array}$ \\
\hline Observations & 224 & 224 & 224 & 224 & 224 & 224 & 224 & 224 & 224 \\
\hline$R$-squared & 0.1927 & 0.0311 & & 0.0171 & 0.0248 & & 0.0367 & 0.0100 & \\
\hline$R 2$ within & & 0.0311 & 0.0294 & & 0.0248 & 0.0236 & & 0.00997 & 0.00996 \\
\hline$R 2$ between & & 0.198 & 0.226 & & 0.0290 & 0.0385 & & 0.0948 & 0.0946 \\
\hline$R 2$ overall & & 0.169 & 0.192 & & 0.0111 & 0.0159 & & 0.0365 & 0.0366 \\
\hline
\end{tabular}

Robust standard errors in parentheses.

${ }^{* * *} P<0.001,{ }^{* *} P<0.01,{ }^{*} P<0.05$.

prices to income per capita by regressing yearly unit values on GDP per capita and use the estimated residuals as our proxy for prices. With the new adjusted unit values, we recalculate the reference prices and reproduce the estimations in Table 5 for price ratios 2 to 4 . The results show a much lower passthrough, negative for price ratios 2 and 3 and positive but very small for ratio 4 .

A final check for the robustness of the results is to estimate the model in differences (9). In order to do so, we compute the annual averages for the variables of interest and apply first differences. The main results for each price ratio are summarized in Table 6 . We also add robust HubertWhite-Sandwich OLS estimates since by differentiating the model we may control for product specific and time invariant quality and cost of compliance costs.

Due to the small sample, we omit from the estimations price ratio 1 specification. The results show a positive and statistically significant coefficient for most of the market share ratio coefficients. This suggests that increases in market share tend to increase price margins. Regarding the main coefficient of interest, the tariff margin, the results suggest a positive coefficient but not statistically significant. Again, there is no evidence that changes in tariff margins are transmitted to price ratio changes.

\section{Conclusions}

The question that we formulated at the beginning of the paper is whether EU unilateral preferences are valuable according to use and price advantage for exporters. In the case of Mozambique, a first element to be stressed is that the joint coverage of both Cotonou and EBA reaches 100\% of the products exported and the large majority of these exports enter duty free under both schemes. On the other hand, 


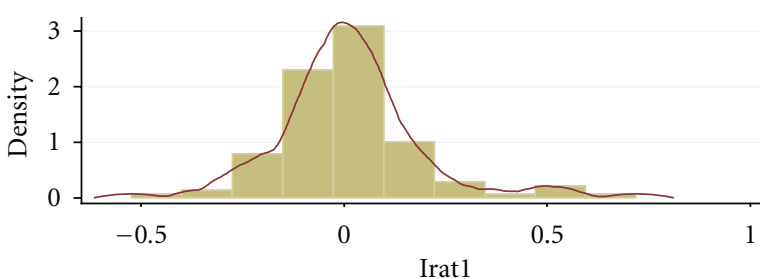

(a)

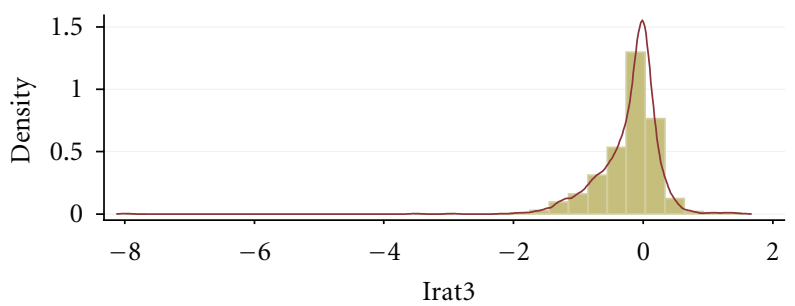

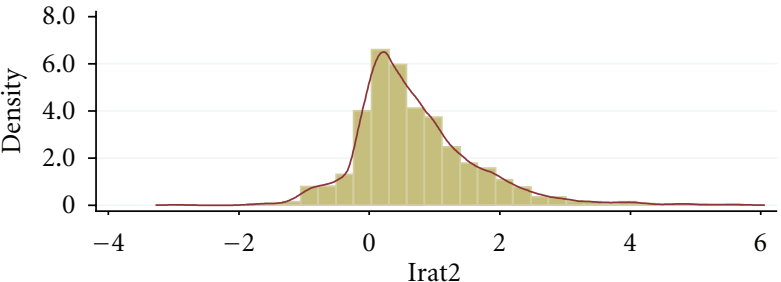

(b)

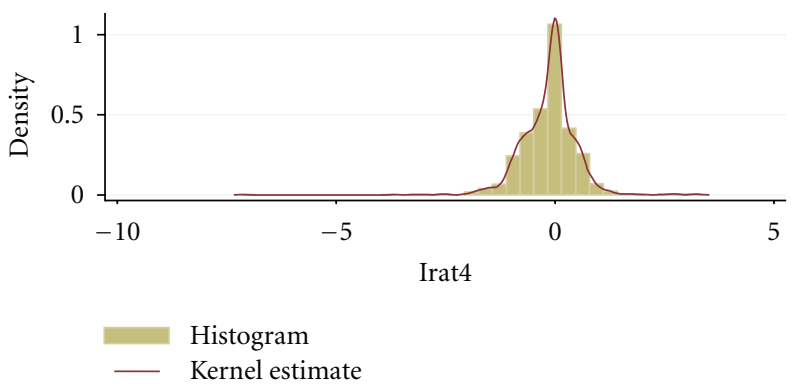

(d)

FIGURE 4: (a) Distribution of Margin_price 1 . (b) Distribution of Margin_price 2 . (c) Distribution of Margin_price 3 . (d) Distribution of Margin_price 4 . Source: authors' calculations.

more than $42 \%$ of the tariff lines and $5.4 \%$ of value exported by Mozambique does not benefit from any "preferential" advantage compared to world exporters (MFN zero). Thus, for these goods, Mozambican firms are able to compete with world exporters without the advantage of preferences. On the remaining exports, Mozambique enjoys a significant de jure preference margin, between $9 \%$ and $12 \%$ (on average).

The second element to be highlighted is the relatively high and fairly stable preference utilization rate $(92 \%$ on average). There are no drops of utilization in correspondence of low tariff margins, suggesting that the negative effect of costs of compliance on utilization does not hold for Mozambican exporters. In addition, since exported products are primary or with very low level of processing, rules of origin are not impacting substantially on producers' costs. Therefore, nonutilization episodes are likely to be the result of sporadic problems in the certification process required by preferential schemes.

A third and more important element is that when comparing unit values, we do not find evidence of a positive price margin for preferential exporters compared to MFN competitors. On the contrary, most statistically significant coefficients indicate a negative relationship between tariff margins and price ratios, suggesting that preferential margins are not passed into exporters' prices. This result is robust to different controls for potential quality biases.

The findings of this paper have significant policy implications. Unilateral preferences are one of the main instruments offered by the EU to foster export growth in developing countries. The findings of the paper indicate, however, that the "value" given to these schemes and their potential impact is likely to be overstated. This is due to the fact that a significant number of products exported by developing countries do not experience any positive preferential margin and, more importantly, the fact that exporters are unable to capture the price margin associated to preferences. Considering these findings and the increasing trend in preference erosion due to further liberalization in the EU market in the future suggest the need to focus in other instruments to support developing countries exports.

A final element to consider is the fact that the potential impact of export preferences goes beyond its limited impact on prices. It is possible that preferences may shape importers' choice among potential suppliers, thus positively contributing to export volume growth in some preference receiving countries. This is an empirical question that we have not analyzed in this paper but that is worth noting. The extension of the analysis to other countries and other preferential schemes may offer some more guidance and should be considered for further research. In addition, more empirical work is needed in order to determine quality differences within product lines.

\section{Acknowledgments}

The authors would like to thank Channing Arndt, Finn Tarp, and Alan Winters for useful comments and suggestions, Ramon Ynaraja for providing relevant data, and DANIDA for financial support. This paper was carried out as part of the trade component of the DANIDA-funded project "Capacity Strengthening and Technical Assistance to the National Directorate of Studies and Policy Analysis" to the Ministry of Planning and Development, Mozambique. A. Alfieri would like to thank USAID for financial support.

\section{Endnotes}

1. This would allow DCs to replace exports of primary commodities that exhibit declining terms of trade, the 
Prebisch-Singer hypothesis (Singer, [2], and Prebisch, [3]), by exports of manufactures.

2. The general equilibrium impact of unilateral export preferences is different from reciprocal liberalization on its impact on the terms of trade, tax revenue, and allocation of the resources between protected, export sectors with preference, and other sectors.

3. Mozal is actually selling to a company belonging to the same multinational group (BHP Billiton) so this export can be classified as intrafirm trade.

4. UNCTAD [9] International Merchandise Trade Indices show that Mozambique's overall export growth between 2000 and 2005 was due to a substantial increase in the quantities exported while export prices remained stagnant.

5. We consider exports as "significant" (nonoccasional) if the amount exported from 2000 to 2005 is higher than 600,000 EUR or if, in the last year (2005), the total exported is higher than 100,000 EUR. In this way, we hope to capture both products being consistently exported by Mozambique in the past as well as emerging exports.

6. For example, rules of origin, safeguards clause, eligibility criteria, and so forth.

7. The COMEXT database establishes that a preference is used when the exporter requests a preferential regime. It is possible, however, that if on arrival EU customs authorities find any problem related to the validity of the certificate of origin or issues related to the eligibility of the shipment to preferential treatment, the shipment will only be allowed to enter under the MFN regime. In these cases, the export flow is classified as preferential when de facto enters the EU via the MFN regime.

8. In order to smooth the series, we apply Hadi's [10] methodology to eliminate outliers at $95 \%$ confidence level to the unit values series. This allows us to eliminate extreme values due to typing errors or due to large quality differences.

9. Except sugar which enters through quotas at a fixed price. Banana and rice are not being exported to the EU.

10. See Alfieri and Cirera [11].

11. Lower MFNs were due to WTO liberalisation schedule; GSP rates changed in 2001 and some FTAs (Chile, Mexico, EUROMED, etc.) came gradually into force in our period of reference.

12. This phenomenon is well illustrated by Schott [12]. He analyses US imports over 25 years and shows that import unit values vary widely within product categories (HS 8-digits) finding evidence of a positive relationship between exporter capital endowment and unit values. That is, capital and skill abundant exporters use their endowment advantage to produce higher quality products and therefore get higher prices. If we assume that MFN exporters are generally middle-high income countries and Mozambique is a LDC, we may expect a severe quality bias in our price ratios, being biased downwards. This feature seems to be confirmed by looking at the average GNI per capita in our sample. Countries exporting through MFN regime show an income per capita two to three times higher than those exporting through preferences.

13. We initially use the minimum cif unit value paid to a MFN exporter in the same month; however, we are forced to exclude it due to quality bias. Price ratios are too large (values between 20 and 50) suggesting that minimum-price-MFN-exporters are not really the most efficient, but those exporting the lowest quality amongst all exporters.

14. Crayfish (HS 03061190), raw sugar (17011110), tobacco products (HS 24012020), yarn and vegetable fibers (HS 53089090), and twine (HS56072990).

15. One common complaint offered by Mozambican private sector firms is that the person in charge of signing certificates is sometimes far from production sites and sometimes absent. In both cases, the exporter would have to waste precious time in order to get the signature entailing an additional cost for preferential exports.

16. We define utilization of preference as the ratio between the value of exports receiving preference and the value of eligible exports-net of products having already a MFN tariff equal to zero.

17. See Brenton [13] on EBA or Manchin [14] on Cotonou and EU GSP.

18. Preferential and MFN exports both face costs due to compliance with quality standards, SPS, and so forth. We assume these costs to be the same and included in the cif unit value. Here, costs of compliance refer exclusively to costs required by preferential schemes due to rules of origin and other documentation.

19. Market share is defined as the ratio between the value of product $i$ exported in year $t$ over total value of imports by the EU of the same product in that year.

\section{References}

[1] B. Hoekman and C. Ozden, "Trade preferences and differential treatment of developing countries: a selective survey," Working Paper 3566, World Bank Policy Research, 2005.

[2] H. W. Singer, "U.S. foreign investment in underdeveloped areas: the distribution of gains between investing and borrowing countries," American Economic Review, vol. 40, no. 2, pp. 473-485, 1950.

[3] R. Prebisch, "The economic development of Latin America and its principal problems," in Economic Bulletin for Latin America, vol. 7, pp. 1-22, CEPAL, Santiago, Chile, 1962, (first published in 1950).

[4] C. Carrere and J. de Melo, "Are rules of origin equally costly? Estimates from NAFTA," in Paper Presented at IDB Conference, Washington, DC, USA, 2004.

[5] O. Cadot, J. de Melo, and A. P. Portugal-Perez, "Rules of origin for preferential trading arrangements," Working Paper 4016, World Bank Policy Research, 2006. 
[6] B. Hoekman, W. Martin, and C. A. Primo Braga, "Preference erosion: the terms of the debate," in Trade, Doha, and Development: A Window into the Issues, R. Newfarmer, Ed., pp. 329340, World Bank, Washington, DC, USA, 2006.

[7] M. Olarreaga and C. Özden, "AGOA and Apparel: who captures the tariff rent in the presence of preferential market access?" World Economy, vol. 28, no. 1, pp. 63-77, 2005.

[8] C. Özden and G. Sharma, "Price effects of preferential market access: the Caribbean Basin Initiative and the apparel sector," Working Paper 3244, World Bank Policy Research, 2004.

[9] UNCTAD, Handbook of Statistics 2006-2007, 2007.

[10] A. S. Hadi, "A new measure of overall potential influence in linear regression," Computational Statistics and Data Analysis, vol. 14, no. 1, pp. 1-27, 1992.

[11] A. Alfieri and X. Cirera, "Unilateral trade preferences in the EU: an empirical assessment for the case of Mozambican exports," DNEAP Discussion Paper 60E, Maputo, Mozambique, 2007.

[12] P. K. Schott, "Across-product versus within-product specialization in international trade," Quarterly Journal of Economics, vol. 119, no. 2, pp. 647-678, 2004.

[13] P. Brenton, "Integrating the least developed countries into the world trading system: the current impact of European Union preferences under "Everything but arms"', Journal of World Trade, vol. 37, no. 3, pp. 623-646, 2003.

[14] M. Manchin, "Preference utilization and tariff reduction in EU imports from ACP countrie," Working Paper 3688, World Bank Policy Research, 2005.

[15] A. Mold, "Trade preferences and Africa: the state of play and the issues at stake," ATPC UN Economic Commission for Africa, 2005.

[16] OECD, "Assessment of utilization and motive for under-utilization of preferences in selected LDCs," October Joint Working Party on Agricultural Trade, COM/AGR/TD/WP(2004)12/REV2, 2004. 


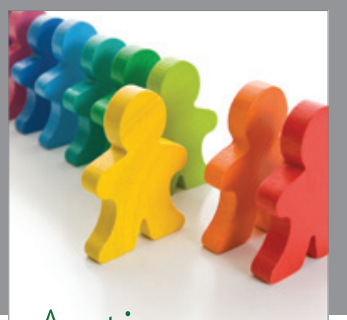

Autism

Research and Treatment
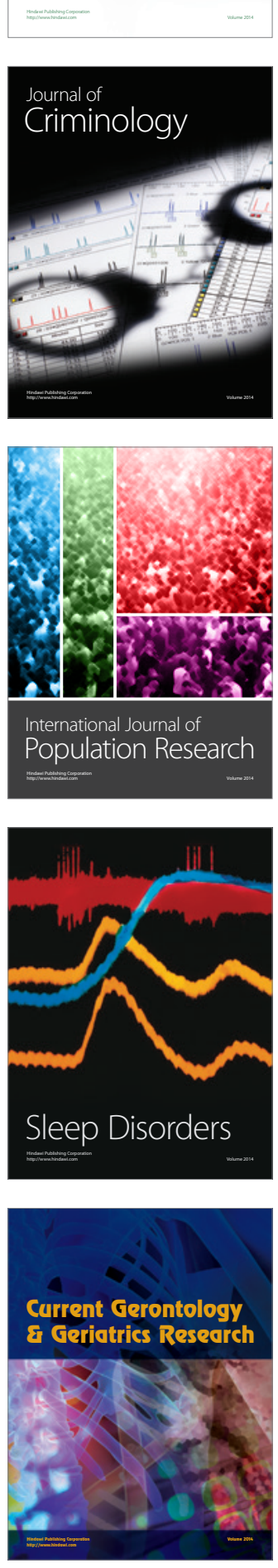
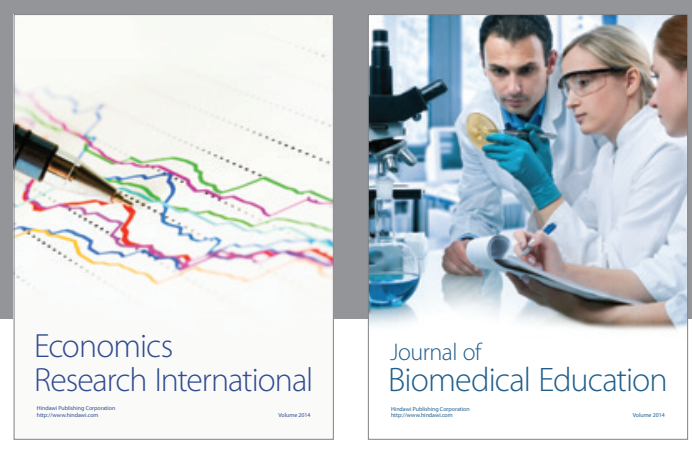

Journal of

Biomedical Education

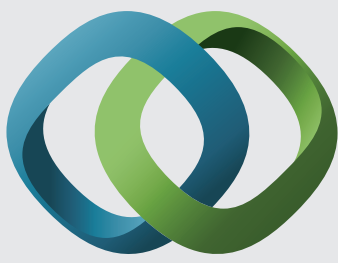

\section{Hindawi}

Submit your manuscripts at

http://www.hindawi.com
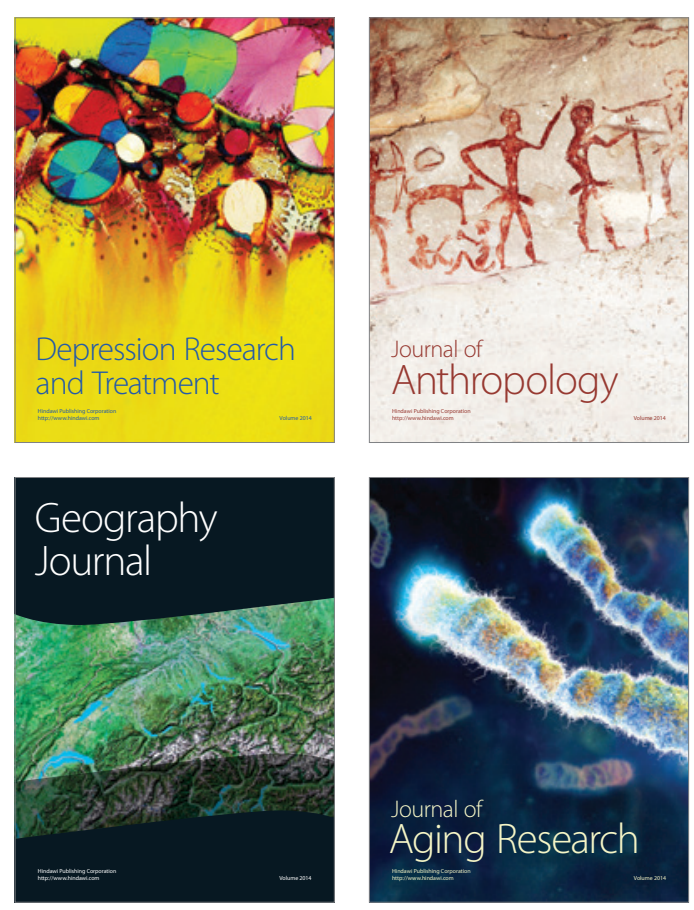

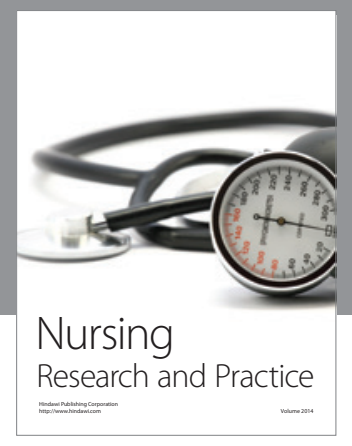

Nursing

Research and Practice

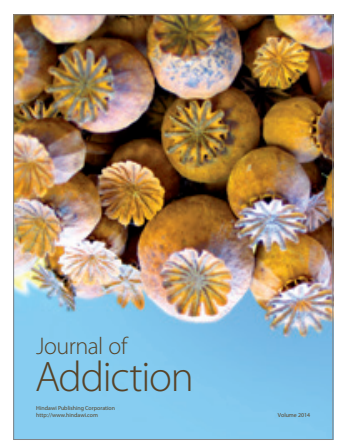

Child Development

Research

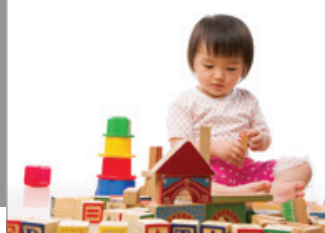

迥
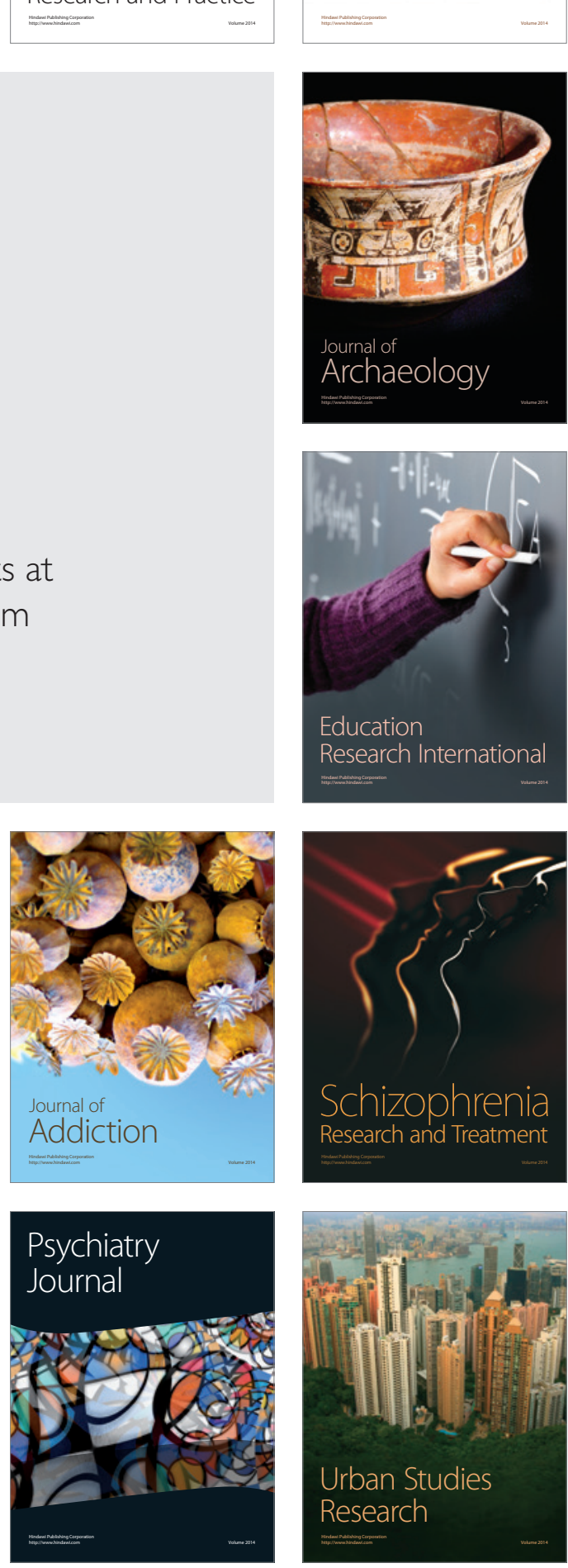